\title{
Exploration of methods used to describe bacterial communities in silage of maize (Zea mays) cultivars
}

\author{
Lorenzo BRUSETTI, Sara BORIN, Aurora RIZZI, Diego MORA, Claudia SORLINI and Daniele DAFFONCHIO* \\ Dipartimento di Scienze e Tecnologie Alimentari e Microbiologiche (DISTAM), Università degli Studi di Milano, via Celoria 2, \\ 20133, Milano, Italy
}

\begin{abstract}
Different techniques to assess bacterial community structure and diversity were evaluated in silages prepared with four different maize cultivars, three conventional and one transgenic (cv. Tundra, event Bt-176). Plants were cultivated in the greenhouse and harvested after 30 days of growth. Silage samples were collected at successive times during fermentation and analyzed for bacterial counts and by various DNA-based fingerprinting techniques. Bacterial counts were similar between cultivars for the total culturable bacteria, sporeforming, and mesophilic and thermophilic lactic acid bacteria (LAB). Further analysis of the species composition of 388 LAB strains by intergenic transcribed spacer (ITS) PCR followed by sequencing of 16S rRNA gene did not reveal differences between cultivars. In contrast, molecular fingerprinting methods targeting whole bacterial communities, such as automated ribosomal intergenic spacers analysis (ARISA) and 16S rRNA gene length heterogeneity-PCR (LH-PCR), indicated that different maize silage batches or cultivars hosted different bacterial communities. Thus, ARISA and LH-PCR fingerprinting techniques offer a fast and sensitive method to compare bacterial communities, and to detect differences in silage bacterial communities.
\end{abstract}

Keywords: silage fermentation / transgenic plants / maize / methods / bacterial communities

\section{INTRODUCTION}

In 2005/2006, about 87.2 millions hectares of genetically modified plants were grown worldwide (Brookes and Barfoot, 2006). Bacterial communities thriving in plant environments are known to be responsive even to small changes in their environmental conditions, including nutrient composition and processing parameters. Changes in plant composition due to phenotypic differences among cultivars may therefore affect the subsequent bacterial community arising in silage, because plant silage is characterized by the bacteria living in close contact with plant material during cultivation. For example, it has been shown that the structure and diversity of the rhizosphere bacterial community vary with plant species and cultivar (Brusetti et al., 2004; Chiarini et al., 1998; Gomes et al., 2001). Hence, transgenic plants also exert cultivar-specific influence on the composition of the rhizosphere bacterial communities (Di Giovanni et al., 1999; Dunfield and Germida, 2001; Gyamfi et al., 2002; Siciliano and Germida 1999).

Silage is made from fine or chopped above-ground plants, which are fermented anaerobically, in a complex interaction between the plant tissue and the epi-

*Corresponding author: daniele.daffonchio@unimi.it phytic microflora (Weinberg and Muck, 1996). Among the components of the epiphytic bacterial community naturally present on the plant leaf surface, lactic-acid bacteria $(\mathrm{LAB})$ play a major role in determining the efficiency of silage fermentation process (Cai et al., 1998; 1999; Lin et al., 1991; 1992). After chopping and ensiling, there is a 300-fold increase of LAB cell number within the first 12-24 h of the fermentation (Lin et al., 1992) and, consequently, LAB metabolism leads to the accumulation of lactic acid in the silage, which decreases the $\mathrm{pH}$ below 5, stabilizing the product, which can be stored anaerobically for long periods of time.

The objective of this study was to evaluate the suitability of different methods commonly used to characterize bacterial communities, to detect potential changes in the silage fermentative bacterial community. These methods ranged from bacterial counts to fluorescent community fingerprinting techniques, such as automated ribosomal intergenic spacer analysis ((ARISA), Fisher and Triplett, 1999) and length heterogeneity-PCR ((LH-PCR), Ritchie et al., 2000; Suzuki et al., 1998), and to typing isolated LAB by intergenic transcribed spacer (ITS)-PCR followed by partial sequencing of the $16 \mathrm{~S}$ rRNA gene. We tested the usefulness of these methods in detecting bacterial community differences in maize silages produced with different maize cultivars, including 


\section{Brusetti et al.}

one expressing the Bacillus thuringiensis Crylab toxin (event Bt-176; Koziel et al., 1993).

\section{RESULTS}

\section{Total bacterial counts}

The counts of the total, aerobic sporeforming bacteria and of mesophilic and thermophilic LAB were determined in silages of parental cv. Tundra and cv. Tundra (event $B t$-176), after 0, 1, 2, 6, 13, 20 and 30 days of fermentation, and in silages of Proxima and Eleonora maize after 30 days of fermentation (Tab. 1). Total cultivable and aerobic sporeforming bacteria and the mesophilic and thermophilic LAB on the fresh plant tissue before ensiling ranged between 0.5 and $3.0 \mathrm{log}$ cfu. $\mathrm{g}^{-1}$ fresh weight. In the first 2 days of fermentation, bacteria grew rapidly: total bacteria, aerobic sporeforming and LAB increased up to $7.9,3.6$ and $7.5 \mathrm{log} \mathrm{cfu}^{-1} \mathrm{~g}^{-1}$ fresh weight, respectively. The number of total and aerobic sporeforming bacteria and mesophilic and thermophilic LAB showed only sporadic differences among the fermentation batches prepared with the different cultivars (Tab. 1).

\section{LAB diversity}

To evaluate if differences could be detected in the LAB species composition within fermentation batches prepared with different cultivars, a total of 388 LAB strains from ensiled cv. Tundra (Bt-176) and the parental conventional cv. Tundra were isolated at different times of fermentation and identified by ribosomal DNA analysis. The strains were grouped by ITS-PCR fingerprinting, and one strain for each ITS-PCR profile was identified by partial $16 \mathrm{~S}$ rRNA gene sequencing. The strains were grouped into 27 different ITS-PCR haplotypes (Tab. 2).

The partial 16S rRNA gene sequences covered between 321 and $556 \mathrm{bp}$, and Table 2 shows the results of the strain identification. The strains belonged to Lactobacillales, such as Weissella confusa (41\% of the strains), Lactobacillus plantarum (13\%), Pediococcus acidilactici (10\%), Lb. perolens $(9 \%)$, Lb. brevis (8\%), P. pentosaceus (6\%), Enterococcus faecium (6\%), W. kimchii (2\%), Lb. paraplantarum $(0.2 \%)$, but also rare Bacillales, such as Bacillus megaterium (3\%). Homofermentative species ( $P$. acidilactici and $P$. pentosaceus), facultative heterofermentative species ( $L b$. paraplantarum, $L b$. plantarum and $L b$. perolens), and obligate heterofermentative species (Lb. fermentum, Lb. brevis, W. kimchii and W. confusa) were found; in particular, homofermentative species were found at the end of fermentation. Changes in species of LAB occurred during the ensiling period. Bacillus megaterium disappeared after one week of ensiling, substituted by Lactobacillales such as Weissella or Lactobacillus. At the late stage of ensiling, Lactobacillus and Pediococcus were predominant. Homofermentative bacteria such as $P$. acidilactici and P. pentosaceus were observable after 20 to 30 days of fermentation. No relevant differences were observed between the fermentation batches in the limited sample size analyzed.

\section{Analysis of the bacterial population structure}

The ARISA analysis of silage showed only a low number of peaks (an average of 10 per sample), however, with a very high total fluorescent emission (Tab. 3). The ARISA fragments ranged between 197 and $702 \mathrm{bp}$. The relatively simple bacterial population structure of the ensiled maize was further confirmed by LH-PCR, which also gave an average of 10 peaks per sample, with a range between 295 and 395 bp (Tab. 3). We previously showed that silage isolates, including Enterobacteriaceae, Bacillaceae, Enterococcaceae and LAB give LH-PCR peak sizes in the range of 344 to $381 \mathrm{bp}$ (Brusetti et al., 2006).

Principal Component Analysis (PCA) of the ARISA peaks is shown as a three dimensional plot (Fig. 1A), explaining $83 \%$ of the total variance. The ARISA profiles obtained at different times of sampling from each fermentation batch clustered in compact groups indicating that the bacterial populations were relatively homogeneous, and suggesting that fermentation-specific changes occurred. The scatter plot showed a separation of the silage total microbiota within the different fermentation batches. Analysis of the molecular variance (AMOVA) of the diversity showed that the differences observed in the scatter plot between the fermentation batches were most often significant $(P<0.05)$ both with the data obtained from the ARISA and with LH-PCR techniques (Fig. 1).

\section{DISCUSSION}

Plants silage is an environment that facilitates close contact between mechanically disrupted plants and actively growing bacteria, where cultivar-specific induced changes in the bacterial composition can be hypothesized. One relevant question regarding the potential environmental impact of transgenic plants is the effect on the bacterial structure and community diversity in their growth habitat (Nielsen et al., 1998). It should be noted that an observable change in bacterial community composition does not necessarily indicate a negative impact, but rather changes resulting from different cultivar properties. Thus, it is important to improve our knowledge of how plant cultivars interact with their associated microbiological communities. Defining the baseline of microbial 
Methods to assess bacterial communities in $B t$-maize silage

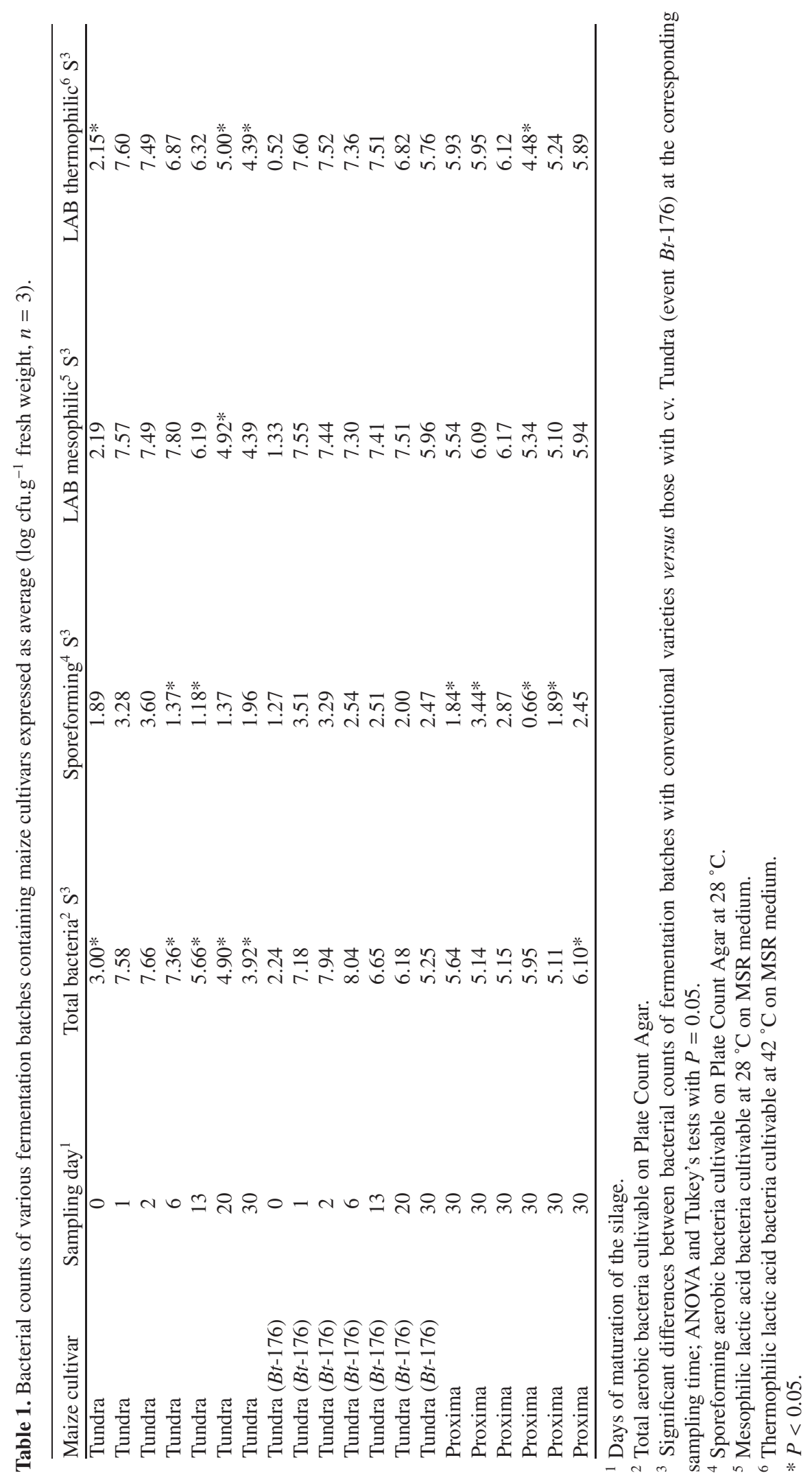


L. Brusetti et al.

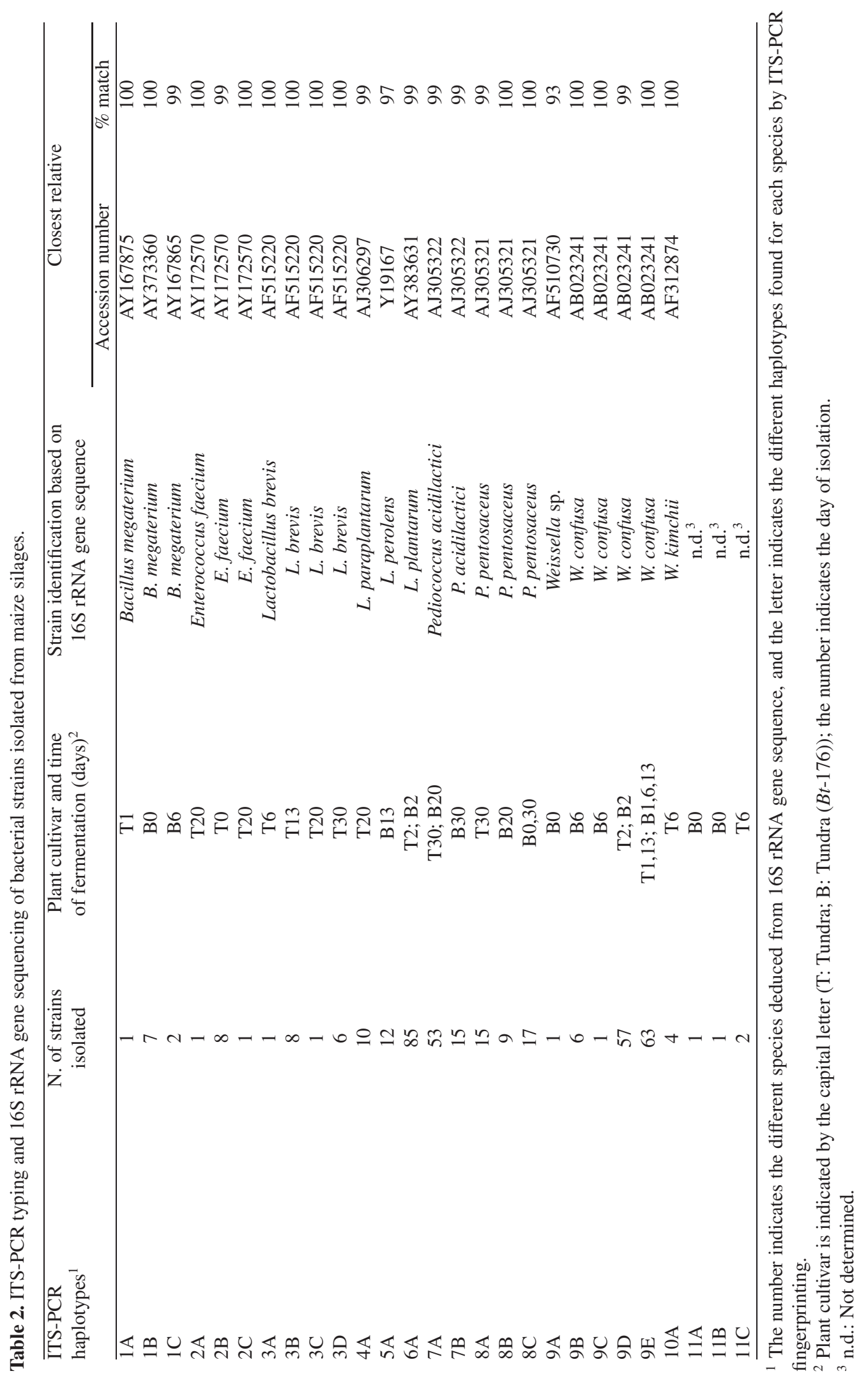




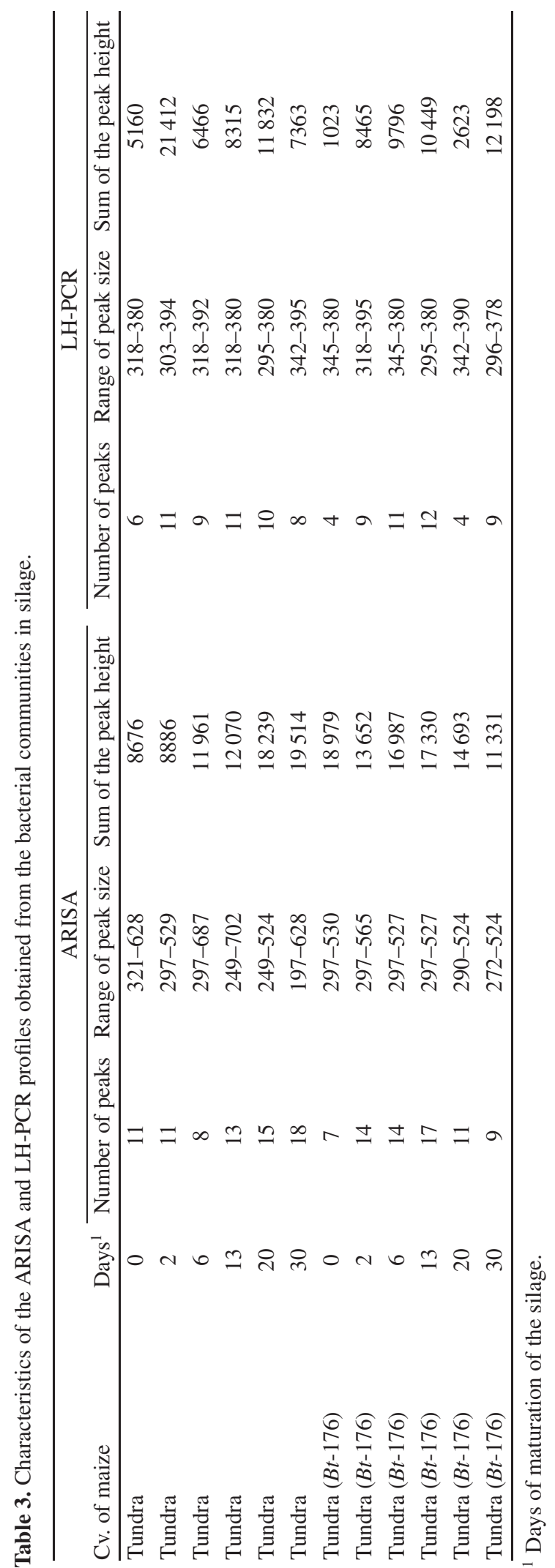




\section{Brusetti et al.}
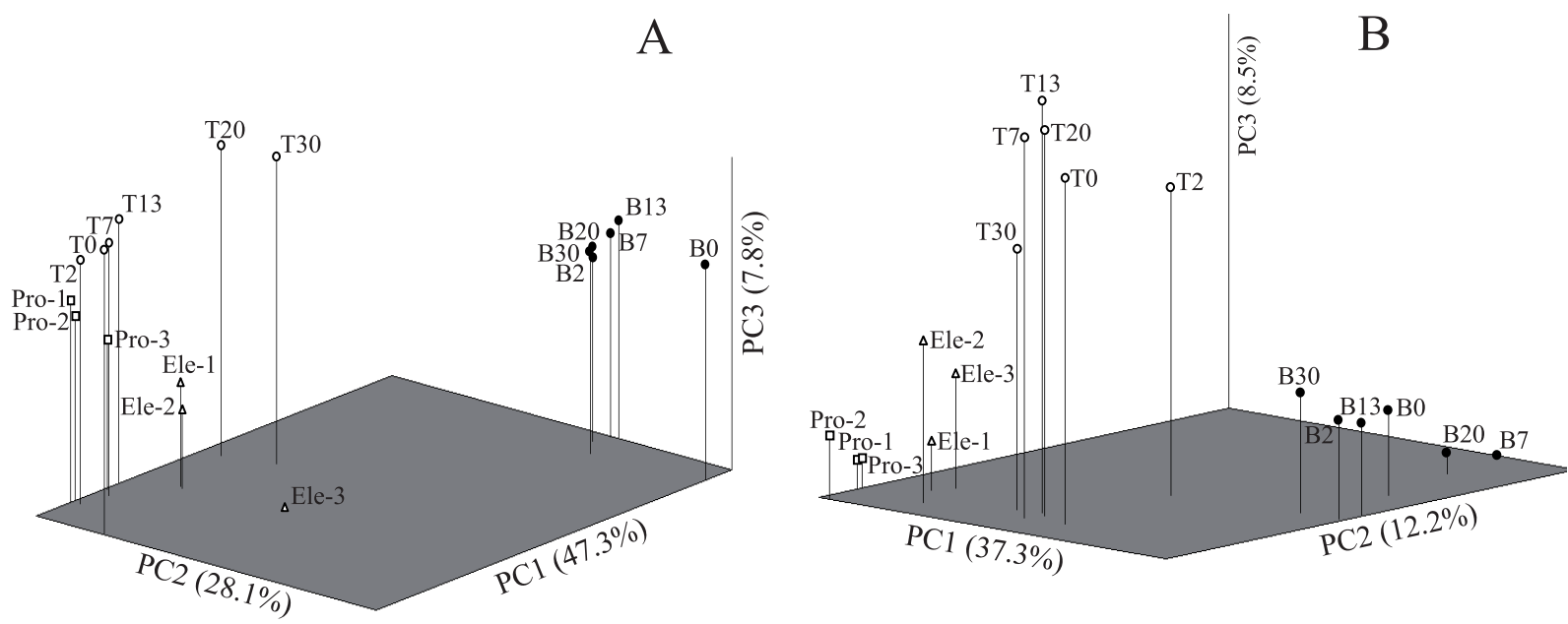

Figure 1. Principal component analysis of ARISA fingerprinting (A) and LH-PCR (B); black circle cv. Tundra (Bt-176) silage, white circle cv. Tundra silage, white square cv. Proxima silage, and white triangle cv. Eleonora silage. Community fingerprinting profiles were obtained for cultivars Tundra (Bt-176) and Tundra at different days of silage maturation, indicated by the numbers in each point, while for cultivars Proxima and Eleonora after 30 days of fermentation.

community dynamics will help further biosafety assessment of novel plant cultivars, particularly those where a credible and testable hypothesis can be put forward concerning a specific effect on the microbiota.

To assess the composition of bacterial communities associated with plants, researchers have used a wide variety of techniques based on the cultivability of bacteria (bacterial counts on different media, strain genomic fingerprinting, species identification, etc.), or based on the analysis of the total bacterial community structure with techniques such as DGGE, SSCP, ARISA or LHPCR targeting housekeeping genes. In the last years, a polyphasic approach, where several techniques are used in parallel, has been commonly used to describe better the bacterial community structure and diversity. A polyphasic approach was used for instance by Costa et al. (2006), Griffiths et al. (2005), Heuer et al. (2002), Smalla et al. (2001), Smit et al. (2001), who reported differences in bacterial community composition of the rhizosphere associated with different plant cultivars.

In this study, we compared various techniques based on cultivability of bacterial isolates (bacterial counts, strains identification) with cultivationindependent molecular methods (ARISA, LH-PCR) in examining the abundance, diversity and structure of the bacterial population within different fermentation batches during the ensiling of four maize cultivars, one of which was the transgenic cv. Tundra (Bt-176). Bacterial counts were done with four different media to assess the density of aerobic copiotrophic bacteria, sporeforming bacteria and mesophilic or thermophilic LAB. The two PCRbased fingerprinting approaches used target either the ITS region of the 16S-23S rRNA gene (ARISA), a region considered to be hypervariable and therefore useful to discriminate bacteria at the subspecies level (Daffonchio et al., 1998), or the 16S rRNA gene (LH-PCR), which is used extensively to distinguish bacterial species. Both ARISA and LH-PCR coupled the characteristics of ITS and 16S rRNA gene analysis with the high sensitivity and precision of capillary electrophoresis. It was previously reported that LH-PCR could display the succession and dynamics of the fermentative microflora during the ensiling process (Brusetti et al., 2006), while ARISA performed with the ITSF/ITSReub PCR primer set performs a powerful evaluation of diversities between different bacterial community structures, reducing the effects due to PCR bias between different environmental samples, maize silage included (Cardinale et al., 2004).

This study demonstrates that both ARISA and LHPCR show a level of discrimination of the bacterial communities in the different fermentation batches examined, as shown by cultivar-specific clustering (Fig 1). Due to the limited number of batches analyzed and samples taken, we cannot draw any conclusions on whether the differences seen are cultivar-specific or represent random variation among batch cultures. The indications of batchdependent community structure were not obtained with the traditional methods examining only a proportion of the cultivable bacteria. The overall number of LAB, the most important functional group in silage, did not vary, suggesting that normal fermentation processes occurred within all the silage batches examined. Furthermore, the $16 \mathrm{~S}$ rRNA gene sequence analysis showed that important 
LAB species like $P$. acidilactici and P. pentosaceous were frequently found in all fermentation batches.

Although pseudoreplicates from the same silage batch were analyzed, multivariate analysis of ARISA and LHPCR data showed significant differences between the fermentation batches, indicating that these techniques are sensitive in detecting minor differences in the structure of complex bacterial communities. Biochemical differences in plant tissue compositions could affect the fine structure of microbial communities thriving in silage, with slight effects (especially on the non-dominant species) detectable only with highly sensitive techniques. Some phenotypic features of maize containing $B t$-toxin, beyond the intended change in the cry protein composition (Saxena et al., 1999), include a higher content of soluble carbohydrates, fructose, nitrogen (Escher et al., 2000) and lignin (Saxena and Stotzky, 2001). These phenotypic changes could potentially influence the less dominant bacterial communities during maize silage fermentation, although the limited sample set analyzed in our experiments was not able to resolve this question.

In conclusion, conventional microbiology techniques based on plating, isolation and sequencing appear to be unable to identify differences between different silage fermentation batches, unless very large sample numbers are used. Moreover, the traditional techniques are very time and labor consuming if adequate samples sizes are to be analyzed. In contrast, automated techniques relying on capillary electrophoresis systems coupled with laser scanning detectors allows representative fractions of community-derived PCR fragments to be separated to provide a broader view of the bacterial community structure developing during ensiling of maize.

\section{MATERIAL AND METHODS}

\section{Maize plants, silage preparation and sampling}

Three conventional maize lines, cv. Tundra (Tun), Novartis, cv. Proxima (Pro), Novartis, and cv. Eleonora (Ele), Pioneer, and one genetically modified insect-resistant (Bt-toxin, Crylab protein) maize, cv. Tundra (event $B t$ 176), Novartis were used in the experiments. The maize plants were grown in a greenhouse in pots (Brusetti et al., 2004). Maize plants were harvested after 30 days of growth. The presence of the transgene construct in $\mathrm{cv}$. Tundra (Bt-176) was verified by PCR (Rizzi et al., 2001; 2003).

Maize plants without of the root system were chopped (average size $1 \mathrm{~cm}$ ) with sterile shears, and about $1 \mathrm{~kg}$ of this material was pressed into sterile glass bottles in an anaerobic chamber and incubated at $30{ }^{\circ} \mathrm{C}$. Silage was sampled (10 g samples) at successive times $(0,2,7,13$,
20 and 30 days of incubation) by opening the microsilos in an anaerobic chamber.

\section{Bacterial counts}

Three two-gram samples were transferred to $18 \mathrm{~mL}$ of sterilized salt solution ( 9 g. $\left.\mathrm{L}^{-1} \mathrm{NaCl}\right)$, and mixed for $20 \mathrm{~min}$ in a blender. The following bacterial counts were performed in agar-solified media from 10 -fold dilutions of each replicate subsample: (i) total aerobic microflora on Plate Count Agar, incubation at $28^{\circ} \mathrm{C}$ for $24 \mathrm{~h}$; (ii) total sporeforming aerobic bacteria on Plate Count Agar after sample pasteurization, incubation at $28{ }^{\circ} \mathrm{C}$ for $24 \mathrm{~h}$; (iii) total mesophilic LAB on MRS plus cycloheximide (0.1 mg. $\mathrm{L}^{-1}$ ) (Difco, Italy); incubation at $28{ }^{\circ} \mathrm{C}$ for $48 \mathrm{~h}$; (iv) total thermophilic LAB on MRS plus cycloheximide (0.1 mg.L $\mathrm{L}^{-1}$ ) and incubation at $42{ }^{\circ} \mathrm{C}$ for $48 \mathrm{~h}$.

\section{DNA sequencing of LAB species}

A total of 388 LAB isolates (190 thermophilic and 198 mesophilic) were randomly isolated from MRS agar plates and restreaking two times. Liquid cultures of each strain $(2 \mathrm{~mL})$ were used for DNA extraction (Ausubel et al., 1994). Three $\mu \mathrm{L}$ of the DNA solution were used in the subsequent PCR reactions. Bacterial 16S-23S rRNA gene ITS of each strain were amplified with primers ITSF and ITSReub (Cardinale et al., 2004). PCR products were run on an agarose gel, and the different ITS-PCR haplotypes were evaluated. Amplification of the 16S rRNA gene of one strain for each ITS haplotype was performed as described previously (Urzì et al., 2001). ITS-PCR fingerprinting patterns were analyzed with the Diversity Database version 2.1.1 (Biorad, Milan, Italy) to number the different haplotypes amplified. The 16S rRNA gene PCR product was purified with QIAquick PCR Purification kit (Qiagen, Milan, Italy) and about $150 \mathrm{ng}$ of the purified PCR product were used in the sequencing reaction using the universal primer 16S-926F (5'-AAACT(CT)AAA(GT)GAATTGACGG3'). Each raw sequence was checked manually and compared with known sequences using the BLAST software package (Altschul et al., 1990). The nucleotide sequences were deposited in the EMBL database under the accession numbers AJ784904 to AJ784927.

\section{ARISA and LH-PCR analysis}

DNA extraction from silage was done according to Brusetti et al. (2006). The concentration of extracted DNA was determined by agarose gel electrophoresis. Then, $50 \mathrm{ng}$ of environmental DNA were used in ARISA 


\section{Brusetti et al.}

and LH-PCR amplifications. Amplification of 16S-23S rRNA intergenic spacers of the bacterial community for ARISA (Fisher and Triplett, 1999) was performed as described previously using ITSF and ITSREub universal primer set (Cardinale et al., 2004). For LH-PCR, purified DNA was amplified according to Brusetti et al. (2006) using universal primers $27 \mathrm{~F}$ and $338 \mathrm{R}$ (Ritchie et al., 2000). ARISA and LH-PCR fragments were loaded on an ABI Prism 310 capillary electrophoresis system, and run in denaturing conditions using the POP-4 polymer. The ARISA and LH-PCR data were analyzed with Genescan 3.1.2 software (Applied Biosystems), and a threshold of 50 fluorescent units was used, corresponding to twice the highest peak detected during the negative control run. Sizing was done with the Local Southern Method and light data smoothing. If the baseline varied inconsistently, the sample was rerun.

\section{Statistical analysis}

For bacterial counts, means and standard deviations were calculated, and analysis of variance of cfu. ${ }^{-1}$ fresh weight was made. Individual means in the ANOVA were compared using Tukey's test (Tukey, 1949). The peak matrices corresponding to the ARISA and LH-PCR profiles were subjected to a principal component analysis. Binary $0 / 1$ matrices were created based on the absence or presence of DNA bands. Pairwise distances were calculated with the SimQual option of the NTSYSpc 2.01 computer program (Applied Biostatistics Inc., USA) by employing the Jaccard coefficient for two-state data.

\section{ACKNOWLEDGEMENTS}

The work was supported by the Italian Ministry for University and Scientific Research. Partial support comes also from the EU TRANSBAC QLK3-CT-2001-02242 and from Consiglio dei Diritti Genetici in the ambit of the project "Organismi geneticamente modificati ed alimentazione: valutazione degli effetti diretti sull'ospite e sulla microflora intestinale", funded by the Cariplo Foundation. We thank K.M. Nielsen for comments on the manuscript.

Received November 17, 2006; accepted November 12, 2007.

\section{REFERENCES}

Altschul SF, Gish W, Miller W, Myers EW, Lipman DJ (1990) Basic local alignment search tool. J. Mol. Biol. 215: 403-410
Ausubel FM, Brent R, Kingston RE, Moore DD, Seidman JG, Smith JA, Struhl K (1994) Current protocols in molecular biology. John Wiley and Sons, eds, USA

Brookes G, Barfoot P (2006) GM Crops: The First Ten Years Global Socio-Economic and Environmental Impacts. ISAAA Brief No. 36, ISAAA: Ithaca, NY

Brusetti L, Francia P, Bertolini C, Pagliuca A, Borin S, Sorlini C, Abruzzese A, Sacchi G, Viti C, Giovannetti L, Giuntini E, Bazzicalupo M, Daffonchio D (2004) Bacterial communities associated with the rhizosphere of transgenic Bt176 maize Zea mays and its non transgenic counterpart. Plant Soil 266: 11-26

Brusetti L., Borin S, Mora D, Rizzi A, Raddadi N, Sorlini C, Daffonchio D (2006) Usefulness of length heterogeneityPCR for monitoring lactic acid bacteria succession during maize ensiling. FEMS Microbiol. Ecol. 56: 154-164

Cai Y, Benno Y, Ogawa M, Ohmomo S, Kumai S, Nakase T (1998) Influence of Lactobacillus spp. from an inoculant and of Weissella and Leuconostoc spp. from forage crops on silage fermentation. Appl. Environ. Microbiol. 64: 2982-2987

Cai, Y, Kumai S, Ogawa M, Benno Y, Nakase T (1999) Characterization and identification of Pediococcus species isolated from forage crops and their application for silage preparation. Appl. Environ. Microbiol. 65: 2901-2906

Cardinale M, Brusetti L, Quatrini P, Borin S, Puglia AM, Rizzi A, Zanardini E, Sorlini C, Corselli C, Daffonchio D (2004) Comparison of different primer sets for the Automated Ribosomal Intergenic Spacer Analysis (ARISA) of complex bacterial communities. Appl. Environ. Microbiol. 70: 61476156

Chiarini L, Bevivino A, Dalmastri C, Nacamulli C, Tabacchioni S (1998) Influence of plant development, cultivar and soil type on microbial colonisation of maize roots. Appl. Soil Ecol. 8: 11-18

Costa R, Götz M, Mrotzek N, Lottmann J, Berg G, Smalla K (2006) Effects of site and plant species on rhizosphere community structure as revealed by molecular analysis of microbial guilds. FEMS Microbiol. Ecol. 56: 236-249

Daffonchio D, Borin S, Frova G, Manichini PL, Sorlini C (1998) PCR fingerprinting of whole genomes, the spacers between the $16 \mathrm{~S}$ and $23 \mathrm{~S}$ rRNA genes and of intergenic tRNA gene regions reveals a different intraspecific genomic variability of Bacillus cereus and Bacillus licheniformis. Int. J. Syst. Bacteriol. 48: 107-116

Di Giovanni GD, Watrud LS, Seidler RJ, Widmer F (1999) Comparison of parental and transgenic alfalfa rhizosphere bacterial communities using Biolog GN metabolic fingerprinting and enterobacterial repetitive intergenic consensus sequence-PCR (ERIC-PCR). Microb. Ecol. 37: 129-139

Dunfield KE, Germida JJ (2001) Diversity of bacterial communities in the rhizosphere and root interior of field-grown genetically modified Brassica napus. FEMS Microbiol. Ecol. 38: $1-9$

Escher N, Käch B, Nentwig W (2000) Decomposition of transgenic Bacillus thuringiensis maize by microorganisms and woodlice Porcellio scaber (Crustacea: Isopoda). Basic Appl. Ecol. 1: 161-169 
Fisher MM, Triplett EW (1999) Automated approach for ribosomal intergenic spacer analysis of microbial diversity and its application to freshwater bacterial communities. Appl. Environ. Microbiol. 65: 4630-4636

Gomes NCM, Heuer H, Schönfeld J, Costa R, MedonçaHagler L, Smalla K (2001) Bacterial diversity of the rhizosphere of maize (Zea mays) grown in tropical soil studied by temperature gradient gel electrophoresis. Plant Soil 232: 167180

Griffiths BS, Caul S, Thompson J, Birch ANE, Scrimgeour C, Andersen MN, Cortet J, Messé A, Sausse C, Lacroix B, Krogh PH (2005) A comparison of soil microbial community structure, protozoa and nematodes in field plots of conventional and genetically modified maize expressing the Bacillus thuringiensis CryIAb toxin. Plant Soil 275: 135-146

Gyamfi S, Pfeifer U, Stierschneider M, Sessitsch A (2002) Effects of transgenic gluphosinate-tolerant oilseed rape (Brassica napus) and the associated herbicide application on eubacterial and Pseudomonas communities in the rhizosphere. FEMS Microbiol. Ecol. 41: 181-190

Heuer H, Kroppenstedt RM, Lottmann J, Berg G, Smalla K (2002) Effects of T4 lysozyme release from transgenic potato roots on bacterial rhizosphere communities are negligible relative to natural factors. Appl. Environ. Microbiol. 68: 13251335

Koziel MG, Beland GL, Bowman C, Carozzi NB, Crenshaw R, Crossland L, Dawson J, Desai N, Hill M, Kadwell S, Launis K, Lewis K, Maddox D, McPherson K, Meghji MR, Merlin E, Rhodes R, Warren GW, Wright M, Evola SV (1993) Field performance of elite transgenic maize plants expressing an insecticidal protein derived from Bacillus thuringiensis. Bio-Technol. 11: 194-200

Lin C, Bolsen KK, Brent BE, Hart RA, Dickerson JT, Feyerherm AM, Aimutis WR (1991) Epiphytic microflora on alfalfa and whole-plant corn. J. Dairy Sci. 75: 2484-2493

Lin C, Bolsen KK, Brent BE, Fung DYC (1992) Epiphytic lactic acid bacteria succession during the pre-ensiling and ensiling periods of alfalfa and maize. J. Appl. Bacteriol. 73: 375-387

Nielsen KM, Bones AT, Smalla K, van Elsas JD (1998) Horizontal gene transfer from transgenic plants to terrestrial bacteria - a rare event? FEMS Microbiol. Rev. 22: 79-103
Ritchie NJ, Schutter ME, Dick RP, Myrold DD (2000) Use of Length Heterogeneity PCR and fatty acid methyl ester profiles to characterize microbial communities in soil. Appl. Environ. Microbiol. 66: 1668-1675

Rizzi A, Agosti F, Daffonchio D, Sorlini C (2001) Detection of genetically modified $B t$-maize in cooked food products by PCR. Ital. J. Food Sci. 13: 265-274

Rizzi A, Panebianco L, Giaccu D, Sorlini C, Daffonchio D (2003) Stability and recovery of maize DNA during food processing. Ital. J. Food Sci. 15: 499-510

Saxena D, Stotzky G (2001) Bt corn has a higher lignin content than non-Bt corn. Am. J. Bot. 88: 1704-1706

Saxena D, Flores S, Stotzky G (1999) Insecticidal toxin in root exudates from Bt corn. Nature 402: 480

Siciliano SD, Germida JJ (1999) Taxonomic diversity of bacteria associated with the roots of field-grown transgenic Brassica napus cv. Quest, compared to the non-transgenic B. napus cv. Excel and B. rapa cv. Parkland. FEMS Microbiol. Ecol. 29: 263-272

Smalla K, Wieland G, Buchner A, Zock A, Parzy J, Kaiser S, Roskot N, Heuer H, Berg G (2001) Bulk and rhizosphere soil bacterial communities studied by denaturing gradient gel electrophoresis: plant-dependent enrichment and seasonal shifts revealed. Appl. Environ. Microbiol. 67: 4742-4751

Smit E, Leeflang P, Gommans S, van den Broek J, van Mil S, Wernars K (2001) Diversity and seasonal fluctuations of the dominant members of the bacterial soil community in a wheat field as determined by cultivation and molecular methods. Appl. Environ. Microbiol. 67: 2284-2291

Suzuki M, Rappé MS, Giovannoni SJ (1998) Kinetic bias in estimates of coastal picoplankton community structure obtained by measurements of small-subunit rRNA gene PCR amplicon length heterogeneity. Appl. Environ. Microbiol. 64: 4522-4529

Tukey JW (1949) Comparing individual means in the analysis of variance. Biometrics 5: 99-114

Urzì C, Brusetti L, Salamone P, Sorlini C, Stackebrandt E, Daffonchio D (2001) Biodiversity of Geodermatophilaceae isolated from altered stones and monuments in the Mediterranean basin. Environ. Microbiol. 3: 471-479

Weinberg ZG, Muck RE (1996) New trends and opportunities in the development and use of inoculants for silage. FEMS Microbiol. Rev. 19: 53-68 